\section{Radioimmune Assay for Histocompatibility Antigens}

A MAJOR obstacle in histocompatibility testing has been the need for whole cells as the final target for antiserum action, for example, haemagglutination, complement fixation or complement-dependent cytotoxicity. Catt and Tregear ${ }^{1}$ have reported that antibody adsorbed irreversibly onto polystyrene test tubes can specifically bind isotope-labelled antigen in nanogram amounts. We have applied a modification of their test to the assay of mouse transplantation antigens.

All operations were carried out at room temperature. One ml. of a dilution of serum in $0.05 \mathrm{M}$ carbonate buffer, $p \mathrm{H} 9 \cdot 6$, was added to polystyrene $(12 \times 75 \mathrm{~mm})$ test tubes (Falcon Plastics) and incubated for $1 \mathrm{~h}$ in an upright position. The antiserum was removed by suction and the tubes were rinsed twice with saline. $0.4 \mathrm{ml}$. of a solution of bovine serum albumin (25 $\mathrm{mg} / \mathrm{ml}$.) in $0.15 \mathrm{M}$ saline, $0.01 \mathrm{M}$ phosphate buffer at $p \mathrm{H} 7.2$ was added to the tubes. The tubes were rotated in a tissue culture roller drum at 20 r.p.m. for $30 \mathrm{~min}$. The solution was removed by suction and $0.25 \mathrm{ml}$. of a solution of the same composition, containing ${ }^{125}$ I-labelled antigen, was added. Incubation was continued in the roller drum for another $3 \mathrm{~h}$. After the tubes were rinsed three times with saline, the amount of ${ }^{126} \mathrm{I}$ bound to the empty tubes was determined in an automatic gamma counter. All assays were performed in triplicate. The presence of $25 \mathrm{mg}$ bovine serum albumin minimized the non-specific adsorption of ${ }^{125} \mathrm{I}$-labelled proteins onto the plastic.

The antiserum used was developed in $\mathrm{C} 57 \mathrm{Bl} / 10 \mathrm{SnJ}$ mice inoculated with the DBA/2 lymphoblast L-5178Y microsomal lipoprotein fraction (MLP), which has been shown to be a potent source of transplantation antigens, both $\mathrm{H} 2$ and non- $\mathrm{H} 2^{2,3}$.

The MLP was labelled according to the method of Hunter and Greenwood ${ }^{4}$. A fresh, dialysed MLP preparation (20 ul. containing $50 \mu \mathrm{g}$ protein) was iodinated with $2 \mathrm{mCi}$ of carrier-free ${ }^{125} \mathrm{I}$ (Amersham Searle). The MLP being insoluble, the unused ${ }^{125} \mathrm{I}$ was removed by dialysis $(4 \times 100 \mathrm{ml}$.) over a 2 day period in the cold.

The extent of specific binding of labelled antigen by various dilutions of the antiserum is shown in Table 1 . Even at a $1: 25,000$ dilution, a significant amount of radioactive antigen was specifically bound. This serum gave a 1 : 160 titre when assayed by conventional complement-induced lysis of $\mathrm{DBA} / 2$ lymphocytes, using trypan blue as an indicator.

Table 2 shows the results of absorption studies performed with this serum. Incubation of the serum with spleen MLP from the strain isogeneic to the serum donor (C57Bl/10) had no effect on the titre in either the radioimmune assay or in the conventional haemagglutination titration. The MLP of congenic resistant-strain spleens, B10.D2, reduced the bulk of the antigen-binding capacity in both tests (approximately 85 per cent in each case). Because the H2D antigen is present in this MLP ${ }^{5}$, the antibody removed was more than likely $\mathrm{H} 2$ antibody. A second absorption with B10.D2 MLP did not reduce the

Table 1. BINDING OF ${ }^{125}$ I-LABELLED L-5178X MLP TO ANTIBODY-COATED

\begin{tabular}{|c|c|c|c|c|}
\hline Antiserum & $\begin{array}{l}\text { Antiserum } \\
\text { dilution }\end{array}$ & $\begin{array}{c}\text { Antigen } \\
\text { bound per } \\
\text { tube (c.p.m.) }\end{array}$ & $\begin{array}{l}\text { Specifle } \\
\text { binding } \\
\text { (c.p.m.) }\end{array}$ & $\begin{array}{c}\text { Spcciflc } \\
\text { binding } \\
\text { (ng protein) }\end{array}$ \\
\hline $\begin{array}{l}\mathrm{C} 57 \mathrm{Bl} / 10 \\
\text { anti L-5178Y }\end{array}$ & $\begin{array}{l}1: 1,000 \\
1: 5,000 \\
1: 6,250 \\
1: 25,000 \\
1: 125,000\end{array}$ & $\begin{array}{l}6,654 \pm 108 \\
4,485 \pm 135 \\
3,830 \pm 473 \\
1,966 \pm 369^{*} \\
1,183 \pm 146\end{array}$ & $\begin{array}{r}5,276 \\
3,107 \\
2,452 \\
588 \\
-195\end{array}$ & $\begin{array}{l}0.67 \\
0.40 \\
0.31 \\
0.08 \\
-\end{array}$ \\
\hline Foetal calf & $\begin{array}{l}1: 50 \\
1: 250\end{array}$ & $\begin{array}{l}1,575 \pm 647 \\
1,468 \pm 210\end{array}$ & $\begin{array}{r}197 \\
90\end{array}$ & \\
\hline $\begin{array}{l}\text { Control } \\
\text { The antiseru } \\
\text { in the text con } \\
\text { * Significant } \\
\text { t The contr } \\
\text { the }\end{array}$ & $\begin{array}{l}\text { ted tubes } \\
378,420 \\
0 \cdot 02 \text { per } \\
\text { s were t } \\
\text { st. }\end{array}$ & $\begin{array}{l}1,378 \pm 302 \dagger \\
\text { exposed to } 0 . \\
\text { (10 ng of } \mathrm{MI} \\
\text { level. } \\
\text { with alkaline }\end{array}$ & of a & $\begin{array}{l}\text { ion described } \\
3 \mathrm{~h} \text {. }\end{array}$ \\
\hline
\end{tabular}

Table 2. ABSORPTION EXPERIMENTS WITH THE ANTI-L-5178Y SEROM

\begin{tabular}{|c|c|c|c|c|}
\hline Treatment & $\begin{array}{r}\text { Sp } \\
1: 250\end{array}$ & $\begin{array}{c}\text { ecific bind } \\
\text { (c.p.m.). } \\
1: 1,000\end{array}$ & $\begin{array}{l}\text { ling } \\
1: 5,000\end{array}$ & $\underset{\text { titre }}{\mathrm{Ha}}$ \\
\hline $\begin{array}{l}\text { Untreated } \\
\text { (a) Absorbed with } 1 \mathrm{mg} \text { C57Bl/10 MLP } \\
\text { (b) Absorbed (a) with } 1 \mathrm{mg} \text { B10.D2 MLP } \\
\text { (c) Absorbed (b) with } 1 \mathrm{mg} \text { B10.D2 MLP } \\
\text { (d) Absorbed (c) } 2 \times 1 \mathrm{mg} \mathrm{DBA} / 2 \mathrm{MLP}\end{array}$ & $\begin{array}{r}1,221 \\
767\end{array}$ & $\begin{array}{r}2,943 \\
2,852 \\
370 \\
702 \\
-207\end{array}$ & $\begin{array}{r}1,752 \\
1,843 \\
-43 \\
-\end{array}$ & $\begin{array}{r}320 \\
320 \\
40 \\
-\end{array}$ \\
\hline
\end{tabular}

* Absorptions were carried out sequentially with the serum used in Table 1 One ml. of the serum was incubated in step $(a) 1 \mathrm{~h}$ at $37^{\circ} \mathrm{C}$, then overnight at $4^{\circ} \mathrm{C}$ on a roller drum (1 r.p.m.). The suspension was centrifuged $30 \mathrm{~min}$ at $100,000 \mathrm{~g}$. The supernatant fluid was titred and subjected to step $(b)$ in the same conditions as for step $(a)$. Steps $(c)$ and $(d)$ were then carried out in succession and the values obtained entered in the table. The values in the table are the specific binding found at the dilution indicated, relative to the original serum. Non-specific absorption with the antigen preparation used was $3,465 \pm 307$ c.p.m. per tube.

$\dagger$ This titration was performed by $\mathrm{Dr}$ J. Palm, using DBA/2 red cells, according to a procedure previously used ${ }^{3}$. The values in the table are the reciprocal of the dilution that was the end-point in the titration.

titre any further. The antigen-combining activity was reduced by absorbing the resulting serum with DBA/2 MLP, a source of non-H2, as well as H2D antigens ${ }^{6}$. It therefore seems that the method will be effective for detecting non- $\mathrm{H}_{2}$ antigens, as well as antibodies directed against these antigens. The final product after these absorptions still had a residual antigen-binding capacity. The nature of this antibody is being investigated further. Further applications of the test will be published elsewhere?

We thank Dr Joy Palm for carrying out the cytotoxicity and haemagglutinating antibody titrations, and Misses R. Crocamo and B. Van Dyke for technical assistance. This work was supported by Public Health Service research grants from the US National Cancer Institute, and a training grant from the US National Institute of General Medical Sciences.

Gabriel V. Foschi

Wistar Institute of Anatomy and Biology,

Lionel A. MANSON

Philadelphia, Pennsylvania 19104.

Received August 18; revised December 17, 1969.

${ }^{1}$ Catt, K., and Tregear, G. W., Science, 158, 1570 (1967).

${ }^{2}$ Manson, L. A., Foschi, G. V., and Palm, J., J. Cell. Comp. Physiol., 61, 109 (1963).

${ }^{3}$ Manson, L. A., Hickey, C. A., and Palm, J., in Biological Properties of the Mammalian Surface Membrane, 93 (edit. by Manson, L. A.) (Wistar Institute Press, Philadelphia, 1968).

4 Hunter, W. M., and Greenwood, F. C., Nature, 194, 495 (1962).

${ }^{5}$ Palm, J., and Manson, L. A., J. Cell. Physiol., 68, 207 (1965). - Manson, L. A., Dougherty, D., Foschi, G. V., and Palm, J., Ann. NY Acad.
Sci.,120, 251 (1964).

'Manson, L. A., Proc. Fourth Intern. Histocompatibility Conf. (in the press).

\section{Simple Method of Subtyping Human G-Myeloma Proteins based on Sensitivity to Pepsin Digestion}

HUMaN immunoglobulin $G$ comprises four subclasses called IgG 1, IgG 2, IgG 3 and IgG 4. G-myeloma proteins result from the proliferation of a single clone of plasma cells and belong to only one of the four possible subclasses. At the present time such myeloma proteins represent the only readily available source of subclass specific protein and are increasingly in demand for both immunological investigations and protein sequence analysis. Subtyping of G-myeloma proteins may be achieved by immunological procedures using subclass specific antisera ${ }^{1,2}$, by Gm typing ${ }^{3}$ or by chemical typing ${ }^{4}$. Early work with G-myeloma proteins of the four subclasses revealed striking differences in sensitivity to papain ${ }^{5,6}$ and these observations have recently been extended by other groups ${ }^{2,8}$ to provide a basis for subtyping. In a recent investigation of the $\mathrm{Gm}$ markers associated with the $\mathrm{pFc}^{\prime}$ fragments of different IgG subclasses $^{9}$, differences were observed between the sub- 